\title{
The influence of signal attributes on the willingness to pay for pasture-raised beef
}

Juliana Chini and Eduardo Eugênio Spers

Department of Economics, Management and Sociology,

Escola Superior de Agricultura Luiz de Queiroz, Universidade de São Paulo, Piracicaba, Brazil

Hermes Moretti Ribeiro da Silva

Department of Production Engineering,

Universidade Estadual Paulista Julio de Mesquita Filho, Araraquara, Brazil, and

Mirella Cais Jejcic de Oliveira

Master and Doctoral Program in Management, Escola Superior de Propaganda e Marketing, Sao Paulo, Brazil

\begin{abstract}
Purpose - This study aims to identify the marginal impact of introducing a signal attribute of pastureraised beef on consumer willingness to pay (WTP) for other independent attributes.

Design/methodology/approach - The study is divided into two steps. The first, qualitative, consisted of investigating the values consumers have regarding beef production. To this end, 52 interviews with Brazilian and US consumers were conducted using laddering. In the second, quantitative, six experiments, (face to face and online) with 267 consumers of beef were performed.

Findings - As a result, the main value found for the Brazilians was security, while for the Americans was self-direction. For consumers, the WTP for animal welfare was the most important in the choice experiments where this information was present.
\end{abstract}

Originality/value - These findings offer an alternate beef differentiation, enabling it to be sold with higher added value by integrating these.

Keywords Experiment, Consumer, Beef, International marketing, Attributes

Paper type Research paper

\section{Introduction}

A single product has several attributes, as it has not only nutritional but also aesthetic characteristics. Moreover, meats present these attributes in different relative proportions. As such, it is not the product itself that offers utility to the consumer, but the features that this product has (Lancaster, 1966). Several studies confirm the importance of identifying how the

(C) Juliana Chini, Eduardo Eugênio Spers, Hermes Moretti Ribeiro da Silva and Mirella Cais Jejcic de Oliveira. Published in RAUSP Management Journal. Published by Emerald Publishing Limited. This article is published under the Creative Commons Attribution (CC BY 4.0) license. Anyone may reproduce, distribute, translate and create derivative works of this article (for both commercial and non-commercial purposes), subject to full attribution to the original publication and authors. The full terms of this license may be seen at http://creativecommons.org/licences/by/4.0/legalcode

Influence of signal attributes

Received 7 February 2019 Revised 30 September 2019 1 April 2020 Accepted 20 May 2020 
RAUSP

55,4

attributes of products lead to consumer purchasing decisions (Evans, 2007; Huber \& McCann, 1982). Attributes are pieces of information that consumers use to form quality expectations. For instance, some create in consumers a strong preference that affects their purchasing intentions (Steenkamp, 1990). Attributes can be classified as independent or signal. The difference between these two categories is that signal attributes are those that provide information about other attributes or the overall quality of a food, while independent ones do not (Gao, 2007).

The choices that individuals make about food affect production systems (Furst, Connors, Bisogni, Sobal, \& Falk, 1996). Given the continuous income growth and the decrease of the income share spent on food, consumers in developed countries have exhausted their basic needs for food and have begun considering additional factors as important (Becker, 2000). In a highly volatile market with different trends in consumer preferences, the "exploration of consumer perceptions of new differentiated products for each process is critical" (Evans, D’Souza, Collins, Brown, \& Sperow, 2011, p. 247).

In literature, food quality is identified as a determinant of national competitiveness and it is important for both producers and consumers (Steenkamp, 1990). Regarding quality, for instance, pasture-raised beef has benefits for human health, the environment and animal welfare (Evans, 2007). Therefore, the demand for beef and cow's milk originating from pasture-raised animals has grown. The reasons for this increase are, namely, the perception of benefits related to health, concern regarding where and how cattle are raised, an intention to support small and medium producers and the view that pasture-raised animals play an important role in the preservation of soil and water (Pirog, 2004).

In the recent international literature of food consumption, several studies explore the preferences of food attributes in different segments, namely, food for children (Li, Chen, Chen, \& Liu, 2019), bread (Gębski, Jezewska-Zychowicz, Szlachciuk, \& Kosicka-Gębska, 2019), vegetables (Cliceri, Spinelli, Dinnella, Ares, \& Monteleone, 2019), chocolate (Palczak, Blumenthal, \& Delarue, 2019), cured meats (Di Vita, Blanc, Brun, Bracco, \& D'Amico, 2019a; Di Vita, Pappalardo, Chinnici, La Via, \& D'Amico, 2019b), sodiumreduced food products (Nguyen \& Wismer, 2019), rice (Ogunleke \& Baiyegunhi, 2019), honey (Testa, Asciuto, Schifani, Schimmenti, \& Migliore, 2019) and Coffee (Cusielo, da Silva, Tavares-Filho, \& Bolini, 2019). Most of these studies were developed in the context of European, North American and even Asian consumers. The purpose of this paper is to explore the Brazilian context and compare northern and southern hemisphere consumers to verify if there are differences between them.

Another gap in the literature that this paper intends to cover is regarding the new consumer food attribute preferences, such as animal welfare (Koknaroglu \& Akunal, 2013 and Hoag \& Lemme, 2018). Recent studies have focused on different animals, namely, poultry (Grandin, 2019), pigs (O’Malley et al., 2019), cattle (Jorquera-Chavez, Fuentes, Dunshea, Jongman, \& Warner, 2019) and venison (Ludwiczak, Bykowska-Maciejewska, Składanowska-Baryza, \& Stanisz, 2019). The empirical investigations are also based on European (Heise \& Theuvsen, 2018; Kirchner, Koštóál, Bilčík, \& Winckler, 2017; Nijland, Aarts, \& Renes, 2013) and North American (Clark, Stewart, Panzone, Kyriazakis, \& Frewer, 2016; McCausland, 2014) consumers.

Finally, this paper investigates the Brazilian willingness to pay (WTP) for meat attributes. In a bibliometric study, only 73 articles published between 1991 and 2014 were found to contain the terms "WTP and food," "WTP and food" (Chini, 2015). They consider traceability (Dickson \& Bailey, 2002; Umberger, 2004; Zhao, Quiao \& Chen, 2010; Loureiro \& Umberger, 2003), food safety certification (Matsumoto, 2004) and green and organic food (Wang, 2007; Makatouni, 2002). Recent literature on WTP in food is also broad and covers 
several attributes, such as luxury restaurants (Kiatkawsin \& Han, 2019), sustainable food (Powell, Jones, \& Consedine, 2019), wine (Di Vita et al., 2019a, 2019b; Tait et al., 2019), probiotics in food (Kolady, Kattelmann, \& Scaria, 2019), eco-labels on fruit (Rihn, Wei, \& Khachatryan, 2019), palm oil (Vergura, Zerbini, \& Luceri, 2019) and nutritional claims (López-Galán \& de-Magistris, 2019).

By observing the relevance of a context where the consumer increasingly demands that products are made using sound environmental practices that also increase food safety, resulting in changes to consumer decision-making, the research problem can be defined as: do consumer preferences for other attributes (independent attributes) change when introducing animal welfare (signal attributes)? Thus, the objective of the study is to identify the marginal impact on consumer WTP for pasture-raised beef when a signal attribute is introduced to other independent attributes. The specific objectives are:

- To investigate consumer values regarding livestock production.

- To determine whether, with additional information, consumer WTP for the signal attribute changes.

\section{Theoretical foundation}

Lancaster (1966) considers that consumer reaction to new products and quality variations is one of the most important aspects related to consumer behavior in an economy. With the increasing concerns about sustainability, nutritional aspects and health-related issues, consumption patterns have been changing rapidly (Hoppe, De Barcellos, Vieira, \& de Matos, 2012). According to Hoppe et al. (2012, p. 176), "food consumer behavior is directly linked to culture, family, environment and also to economic reality."

When it comes to understanding culture, the study of values is essential (Pato-Oliveira \& Tamayo, 2002). For Schwartz (1992, p. 4), values "are concepts or beliefs; pertain to desirable end states or behaviors; transcend specific situations; guide selection or evaluation of behavior and events; and are ordered by relative importance." Schwartz (1992) classified values into 10 types, namely, power, achievement, hedonism, stimulation, conformity, selfdirection, universalism, benevolence, tradition and security.

Values are important when evaluating products and their attributes. For Lancaster (1966), a product consists of a set of attributes (not the product itself) that offers utility to the consumer. The attributes for pasture-raised beef are described below. The aim of this study is to show alternate frameworks for the attributes under consideration.

Consumer WTP is the maximum price a consumer would pay for a product, which corresponds to the value he/she attributes to it (Kalish \& Nelson, 1991; Wertenbroch \& Skiera, 2002). Understanding how consumers react to price changes or how much they would be willing to pay for a new product or service is considered a competitive differentiator because in addition to the predictive character, WTP identifies the value assigned to a product or service. Understanding consumers is crucial to estimate demand, optimize prices, create value, develop new products and make promotional decisions (Anderson, Jain \& Chintagunta, 1992; Wertenbroch \& Skiera, 2002; Schmidt, \& Bijmolt, 2019). Le Gall-Ely (2009) states that, if a price can be customized, knowing consumer WTP can optimize volume and sales margins.

There is a relationship between WTP and the perception of benefits-positioning strategies (Davvetas, Sichtmann, \& Diamantopoulos, 2015; Cheah, Ting, Thaichon, Fam \& Bazylewich, 2020). Understanding consumer WTP contributes to an understanding of the extent of the positive influences of perceived brand globalness and how it influences price (Davvetas et al., 2015). In addition, consumer WTP can be increased by a positioning
Influence of signal attributes 
RAUSP

55,4

438

strategy that increases consumer satisfaction or loyalty (Cheah et al., 2020) or with price discrimination based on costs and value delivered to customers (Homburg, Lauer \& Vomberg, 2019).

Consumer WTP a premium price for a brand with perceived quality, perceived value over cost and uniqueness, can establish consumer-based brand equity (Low \& Lamb, 2000). In addition, as a brand is an attribute set, it is important to understand the amount of money that consumers are willing to pay for the main attributes of a brand, such as the country of origin and sustainability (Koschate-Fischer, Diamantopoulos \& Oldenkotte, 2012).

According to Stewart, O'Shea, Donaldson, and Shackley (2002), the literature on consumer WTP is scarce, most studies focusing on whether there is an ordering effect when multiple contingent valuations are requested in a single research instrument. The term appeared in literature in the early 2000s, when WTP began to be used to determine the price of public goods and services (Le Gall-Ely, 2009). For Kalish and Nelson (1991), this maximum price is equal to the value of the product to the consumer, and is also considered to be the consumer's reservation price for the product. According to the authors, consumers compare their reservation price with the price of each product they purchase, opting for the one that offers a distinct advantage.

Consumers purchase a product from a set of alternates. Generally, the product chosen is the one for which its WTP exceeds the purchase price (Wertenbroch \& Skiera, 2002). For Scholz, Dorner, Franz, and Hinz (2015), WTP is an essential contribution to business models, forecasting and optimization, as it helps decision-makers define efficient pricing strategies. Le Gall-Ely (2009) adds that, when there is no information or data available, such as when a product is still under development or for public goods, WTP is an interesting alternate to the price elasticity of demand. For Gao and Schroeder (2009), consumer WTP for certain food quality attributes is an important indicator of consumer response, making an understanding and estimation of it relevant to policymakers and producers. Furthermore, choice experiments (CE) that compare various WTP scenarios offer detailed insights in the investigation of consumer preferences (Gao \& Schroeder, 2009).

According to Harper and Makatouni (2002), animal welfare is used as a proxy for other attributes, such as the impact of health and safety. Gao (2007) showed that, as additional attributes are presented to consumers, the WTP for a signal attribute changes. Thus, the first hypotheses of this study are posited as follows:

H1a. Consumer WTP for the attribute "guaranteed animal welfare" is greater than for other attributes.

H1b. Consumer WTP for the signal attribute "guaranteed animal welfare" decreases when independent attributes are added.

Studies have found that tenderness is the most important attribute in beef choice (Feldkamp, Schroeder, \& Lusk, 2003; Goss, Holcomb, \& Ward, 2002; Huffman et al., 1996; Lusk \& Fox, 2000; Lusk, Roosen, \& Fox, 2003). Based on these studies, this paper also aims to test the following hypothesis:

H2. Consumer WTP for the attribute "guaranteed tenderness," present both in the pasture- and feedlot-raised beef, is greater than for the signal attribute "guaranteed animal welfare."

The literature review, presented in the following section, provided the basis for the methodology of this study. 


\section{Methodology}

Consumer behavior is affected by inherent values and the image that consumers have about a product, service or brand. In other words, consumer opinion is shaped by attributes. Simonson and Drolet (2004) suggest that instead of estimating the value of a product to target consumers and estimating its price accordingly, marketers should investigate the factors that affect consumer price perceptions. Therefore, this study is divided into two parts. The first aims to investigate the image that a consumer has when identifying the attributes that compose different aspects of the beef chain and the value behind them. The second is to estimate consumer WTP for such attributes.

\subsection{Step 1: qualitative research with consumers}

The first step was to investigate the values of beef consumers in Brazil and the USA regarding beef production. To do so, the laddering technique was used to understand how individuals translate attributes into significant associations, which involved a series of "why is it important for you?" questions. The purpose of this technique is to determine sets of relationships between the key elements of all attributes $(A)$, consequences $(C)$ and values $(V)$ (Reynolds \& Gutman, 1988).

Reynolds and Gutman (1988) propose a sequence of steps for data analysis. First, it is necessary to conduct a survey on consumer perception using the question "why is this important to you?" repetitively. Then, content analysis and standardization of the key elements should be conducted. After that, an implication matrix is created, which shows the number of connections between key elements, accounting for the direct and indirect relationships between them. Finally, means-ends chains are structured with a mapping that is a diagram showing the connections between the attributes, values and consequences (Pinto, Murakami, Pimenta, \& Nunes, 2012).

In the first part of the questionnaire, the respondent named words that characterize beef production, such as production, producer, consumer and marketing. After that, the respondent was asked to assign importance and order attributes, the most important of which were used for laddering. For example, if in the first part, when asked about words that characterize production, the respondent replied "cattle," in the second part he/she was asked "why is the word 'cattle' the most important to you?" followed by "why is the answer above important to you?"

To analyze the data, the content of the interviews was first examined through the construction of a table that divided the responses into attributes (A), consequences (C) and values $(V)$. The attributes and consequences were grouped according to similarity. From this table, a hierarchical value map was built using MECanalyst software, developed specifically for laddering. The relationships with low incidences were disregarded and a cutoff point of two was established. This covered around $80 \%$ of relationships, being consistent with Reynolds and Gutman (1988), who recommend between $75 \%$ and $80 \%$. Finally, values were classified according to the 10 types of motivational domains of Schwartz (1992), namely, power, achievement, hedonism, stimulation, self-direction, universalism, benevolence, tradition, conformity and security.

The research sample included a total of 58 respondents (32 Brazilian and 26 American consumers). However, as laddering does not accept incomplete answers, six were excluded, resulting in a total of 52 respondents ( 30 consumers from Brazil and 22 from the USA). The questionnaires for the North American consumers were conducted in February 2013, in Columbus, Ohio and the sample comprised students and staff at Ohio State University. In July and August of the same year, the research was conducted with end users in Campinas and Piracicaba, a region in Brazil known for its high-level consumer demand. In Campinas,
Influence of signal attributes 
RAUSP

55,4

the questionnaires were conducted in the city's downtown streets and at a leisure park. In Piracicaba, the questionnaire was applied to college students and acquaintances of the researchers.

\subsection{Step 2: quantitative research - experiment in Brazil}

Social science researchers have used experiments to identify, monitor and quantitatively measure variables that affect the motivation of an individual or group (Holloway, \& White, 1964, p. 63). In this study, a CE was conducted, in which pre-determined attributes are chosen based on the belief that they will have a major impact on consumer decisions. The CE simulates real-life purchasing situations, and is thus, expected to provide more reliable WTP estimates than hypothetical valuation questionnaires (Tonsor, Schroeder, Fox, $\&$ Biere, 2005). Respondents must choose an alternate to maximize their usefulness based on the random utility theory (Gao, House, \& Yu, 2010). They have choice alternates, in which the products are defined by their attributes. Price is one of them and when individuals make their choice, "they implicitly make trade-offs between the levels of the attributes of the different alternates presented in a choice set” (Alpizar, Carlsson, \& Martinsson, 2003).

Through CEs, the WTP for the choices made can be measured (Mahieu, Andersson, Beaumais, Crastes, \& Wolff, 2014). For Gao and Schroeder (2009), the WTP for certain food quality attributes is an important indicator of consumer response and the understanding and estimation of it is relevant to policymakers and producers. Further, comparisons between the various WTPs in CEs allow the investigation of consumer preferences (Gao \& Schroeder, 2009).

\subsection{Theoretical model and estimate}

The theoretical model is based on consumer utility, showing that when there are changes in the number of attributes in the utility function, consumer WTP for a specific attribute also changes. Thus, the authors define a linear and random utility function, as shown in the following equation:

$$
U_{i j}=\propto_{i} \cdot p_{i j}+\sum_{k=1}^{T} \beta_{i k} \cdot x_{i j k}+\varepsilon_{i j}
$$

where $\propto_{i}$ is the marginal utility of price by the person $i$, $p_{i j}$ the price of alternate $j$ by the person $i, \beta_{i k}$ the marginal utility of $k$-th attribute, $x_{i j k}$ the $k$-th attribute of alternate $j$ by the person $i, \varepsilon_{i j}$ the stochastic disturbance of alternate $j$ by the person $i$ and $T$ the number of attributes of alternate $j$ (Gao \& Schroeder, 2009).

Consumer WTP $(i)$ is the amount the individual will pay to maintain their level of utility when the $k$-th attribute changes (Gao \& Schroeder, 2009). Assuming that for the $k$-th alternate, $j$ improves from level 0 (without the attribute $k$, superscript 0 of the attribute $x$ ) to level one (with attribute $k$, superscript 0 of the attribute $x$ ), the WTP of consumer $i$ to accept the price he/she would like to pay for this change is represented by the following equation:

$$
\propto_{i} \cdot p_{i j}+\sum_{h=1 h \neq k}^{T} \beta_{i k} \cdot x_{i j k}^{0}=\propto_{i} \cdot\left(p_{i j}+W T P^{k}\right)+\sum_{h=1 h \neq k}^{T} \beta_{i k} \cdot x_{i j k}+\beta_{i k} \cdot x^{1} i j k .
$$

Solving equation (2) yields: 


$$
W T P^{k}=-\frac{\beta_{i k}}{\propto_{i}}\left(x_{i j k}^{1}-x_{i j k}^{0}\right)
$$

Influence of signal

Thus, the linear function of the WTP utility for the $k$-th attribute is the negative ratio of the attributes parameter of $k$ in relation to the price (Gao \& Schroeder, 2009): $W T P^{k}=-\frac{\beta_{i k}}{\alpha_{i}}$. As the objective of the study is to test the effect of additional attributes on consumer WTP for attribute $k$, it is assumed in equation (1) that alternate $j$ has additional $M-T$ attributes $(\mathrm{M}>\mathrm{T})$, which changes the linear and random utility function of consumer $i$ to:

$$
U_{i j}^{*}=\propto_{i}^{*} \cdot p_{i j}+\sum_{k=1}^{T} \beta_{i k}^{*} \cdot x_{i j k}+\sum_{k=T+1}^{M} \beta_{i k}^{*} \cdot x_{i j k}+\varepsilon_{i j} .
$$

Additionally, when adding attributes to the function, the marginal utility of the consumer changes from $\propto_{i}$ to $\propto_{i}^{*}$ and from $\beta_{i k}$ to $\beta_{i k}^{*}$, changing the WTP for attribute $k$ from $W T P^{k}=-\frac{\beta_{i k}}{\alpha_{i}}$ to $W T P^{k^{*}}=-\frac{\beta_{i k}^{*}}{\propto_{i}^{*}}$. Then, this model was used to verify whether "WTP" is different from "WTP ${ }^{k^{*}}$."

For the estimation, the mixed logit model, also known as the random parameters logit (RPL) model was used, due to its flexibility to simulate any random utility mode, and also the fact that it does not have the limitations of other logit models, such as homogeneous preferences among individuals, the pattern of limited substitution between alternates or the non-permission of the correlation on unobservable factors through the choice options of each individual. In the RPL model, "the mean of the random parameters is estimated, together with their variance, while in the standard logit, the variance is set equal to zero" (Nahuelhual, Loureiro, \& Loomis, 2004, p. 544). Thus, the attributes with random coefficients will have a distribution around the mean.

The bootstrapping procedure of Krinsky and Robb (1986) was used to generate 1,000 parameters that enabled calculating 1,000 WTPs for each attribute in all CEs, in addition to estimating the average and variance. As the coefficients on meat attributes have a normal distribution and the price is not a random parameter, the ratio between the coefficients on attributes and price also has a normal distribution. Thus, the WTP averages for each CE were calculated by a $T$-test (mean-comparison test). All statistical analyzes were performed using the Software for Statistics and Data Science 13 software, except for the descriptive ones, for which Statistical Package for the Social Sciences 19 was used.

\subsection{Design of experiments and questionnaires}

In the first step, questionnaires were distributed and a survey was conducted with 14 clients of "beef passion" at their butcher's store in São Paulo. In the second step, a survey was conducted through Qualtrics, a web-based survey tool, which randomly alternated between the four questionnaires (Table 1 below). The respondents accessed the link "Blog da Carne"

\begin{tabular}{llrr}
\hline Questionnaire & \multicolumn{3}{c}{ Choice experiments } \\
\hline A12 & A11 & A12 & Table 1. \\
A23 & A21 & A22 & Alternates and \\
B12 & B11 & B12 & experiments \\
B23 & B21 & B22 & . \\
\hline
\end{tabular}


RAUSP

55,4

(meat blog), which was shared through social media. In the third step, 54 students of the management course at Luiz de Queiroz College of Agriculture, Piracicaba Campus, University of São Paulo also answered the questionnaires.

The total resulting sample comprised 267 consumers. According to Ward, Lusk, and Dutton (2008), samples may be small, medium or large, with approximately 250, 500 or 1,000 respondents, respectively. The question "are you a vegetarian?" was used as a filter, and only those who answered "no" could continue answering the questionnaire.

For the experiments, two sets of attributes of a prime steak were used, based on the study of Gao and Schroeder (2009). The first set was used to test the effect on consumer WTP when an additional signal attribute was introduced. In a $\mathrm{CE}$, the minimum number of attributes should be at least two and no more than five, as a larger number may lead to information overload for respondents (Gao et al., 2010).

Five attributes directly related to pasture-raised meat were chosen according to the hypotheses of this study. The sixth attribute was the price. The first set consisted of: price per 100-gram steak, Guaranteed omega 3, guaranteed leanness and guaranteed Vitamin E. The second, which was used to test the additional effect on consumer WTP if no signal attribute were presented, included: Guaranteed omega 3, guaranteed leanness and guaranteed tenderness.

Four different prices were used for prime steak, considering the average price, two higher and one lower. For the animal welfare, Omega 3, Vitamin E, guaranteed thinness and softness attributes, two levels were used, namely, yes and no, which refer to being present or not.

To test the effect of adding animal welfare attribute information (attribute not known) a sequence of CEs with three, four and five meat attributes that were presented to consumers for both groups was devised. As can be observed, three experiments were constructed for each group, totaling six experiments, namely, A11, A12 (21), A22 (with the unknown attribute), B11, B12 (B21) and B22 (without the unknown attribute).

The first experiment had three attributes, the second four and the third five. The number starts with three because it indicates the number of attributes present in each experiment of choice. All three experiments had the same number of choices to reduce the complexity that may affect respondents' decisions. Orthogonal factorial fractional design was chosen to reduce the number of alternates of the $\mathrm{CE}$.

Three sets of alternates were chosen with the number of attributes for the alternates being three, four and five. The first attribute has four levels, corresponding to the four corresponding prices, and the other attributes have only two levels, "yes" or "no" $(0,1)$. Thus, there were three sets of alternates, each with eight original attributes. The number of alternates in each set was three, four and five, respectively, and these drawings with all three alternate sets have a 100\% D-efficiency (Gao, 2007).

In the second step, the eight original attributes in each group were randomly ordered to create eight pairs of alternates, i.e. sets of choices, along with the original alternates, generating three CEs. In the last step, the numeric attribute levels were labeled with corresponding attribute levels for the steaks. In addition, for each choice set, the "none" alternate was added to make the choice more realistic, as consumers could choose this option when shopping (Gao \& Schroeder, 2009; Lusk \& Schroeder, 2004). In Step 3, three alternates of $\mathrm{CE}$ were generated. Thus, there were six experiments in total, three with the unknown attribute and three without the unknown attribute.

For each of the eight choices in each experiment, there were three alternates (Option A, B or neither). Two of the three experiments (A1, A2, A3 or B1, B2 and B3) were selected to build a series of questionnaires: the first, A12, included experiments A11 and A12; the 
second, A23, included experiments A21 and A22; the third, B12, included experiments B11 and B12; and the fourth, B23, included experiments B21 and B22, as shown in Table 1.

\section{Results}

\subsection{Laddering}

The values of consumers regarding beef production were the object of investigation in the first step. The content analysis identified four attributes, six consequences and three values for Brazilian consumers and four attributes, eight consequences and five values for the USA consumers. Table 2 organizes these elements by country.

For Brazilian consumers, the most important values related to livestock production are universalism and security. The first had a greater number of incidences and shows that respondents view production as a way to provide food for the general population. Moreover, the value security showed that they link production to health and food safety.

In the case of US consumers, the main value was self-direction, followed by safety. The first is connected to consumer choice. According to the respondents, despite production having negative aspects, it is up to consumers whether to consume, what to consume and also to seek information about the origin and production method. However, they considered meat as a food necessity and that it should be safe.

Finally, consumers from both Brazil and the USA, in addition to the values that they have for beef production, consider aspects concerning livestock that relate to signal attributes and, in the case of this study, animal welfare, to be important. In the case of Brazil, the concern for the values of health and security were considered important in the analysis. These factors relate to this study, in which the preference for attributes such as animal welfare, Omega 3, leanness and Vitamin E were identified. In addition to this qualitative approach analysis, another one was carried out with beef exports.

\subsection{Choice experiments}

In October 2015, the three steps of the experiment were performed. First, the questionnaires were administered to 14 customers of the "beef passion" butcher's store in São Paulo. The survey was also shared on social media through "Blog da Carne," through which 210

\begin{tabular}{|c|c|c|}
\hline Attributes & Consequences & Values \\
\hline \multicolumn{3}{|l|}{ Brazil } \\
\hline 1. Production aspects & 5. Feeling & 11. Achievement \\
\hline 2. Security & 6. Quality & 12. Universalism \\
\hline 3. Animal & 7. Food & 13. Security \\
\hline \multirow[t]{3}{*}{ 4. Quality } & 8. Health & \\
\hline & 9. Accessibility & \\
\hline & 10. Production aspects & \\
\hline \multicolumn{3}{|l|}{ USA } \\
\hline 1. Necessity & 5. Animal & 13. Power \\
\hline 2. Production aspects & 6. Production aspects & 14. Self-direction \\
\hline 3. Negative & 7. Origin & 15. Universalism \\
\hline \multirow[t]{5}{*}{ 4. Animal } & 8. Financial/economic aspects & 16. Security \\
\hline & 9. Choice & 17. Achievement \\
\hline & 10. Feeling & \\
\hline & 11. Food & \\
\hline & 12. Necessity & \\
\hline
\end{tabular}

Influence of signal attributes \\ -}


RAUSP

55,4

questionnaires were answered, of which 199 were complete, and thus, used in the analysis. Finally, 54 questionnaires were answered by students of the management course at Luiz de Queiroz College of Agriculture, Piracicaba Campus, University of São Paulo.

4.2.1 Results of econometric models. A total of 267 questionnaires were completed (78 of A12, 62 of A23, 60 of B12 and 67 of B23). Eight logit models of random parameters were estimated for each of the eight CEs. The alternate price coefficient is a non-random parameter because if it were assumed that the price coefficients followed a normal distribution, some people would have had positive price coefficients, which is not consistent with the price-demand relationship. Not allowing the price coefficient to vary randomly "also ensures that WTP estimates for a particular steak are normally distributed" (Tonsor et al., 2005).

Coefficients on meat attributes used in the study were defined as random parameters following a normal distribution to enable consumers' heterogeneous preferences for these attributes. The assumption that random parameters follow a normal distribution is the most widely used (Nahuelhual et al., 2004). The normal distribution enables the coefficients to be positive or negative, and, thus, the WTP estimates may be positive or negative (Lusk, Roosen, \& Fox, 2003; Nahuelhual et al., 2004; Tonsor et al., 2005; Train, 1998). Moreover, the proportion of the sample for each signal is determined by the estimated mean and standard deviations (Train, 1998).

The coefficients were also classified as correlated "because in CEs, each respondent makes sequences of choice decisions with several (eight in our case) choice sets, individual preferences are perfectly correlated across the choice sets for a given respondent" (Gao, 2007, p. 55). Table 3 shows the coefficients on the attributes of the products under the four questionnaires.

Aside from the Guaranteed omega 3 and Vitamin E, for choice A22, all coefficients were different from 0 at a $5 \%$ significance level. The coefficient price was negative in all situations of choice and the coefficients on the other attributes were positive, which is consistent with the price-demand relationship. The standard deviation distributions of each attribute show that there are heterogeneous preferences for meat attributes. However, the attribute "Guaranteed omega 3" in CEs A12 and A21 and attribute "guaranteed leanness" in A22 were not statistically significant at $5 \%$.

For the four CEs of questionnaires B12 and B23, coefficients on all attributes except "Guaranteed omega 3" and "guaranteed Vitamin E," both in B22, were different from 0 at a significance level of $5 \%$. The coefficients on price are negative in all choices and the other attributes positive. Although the coefficient on "guaranteed Vitamin E" has a negative sign in B22, it was not statistically significant.

In Table 4, the negative covariance between "guaranteed animal welfare" and "Guaranteed omega 3" (A12), presented in the matrix of random parameters to questionnaires A12 and A23, indicates that the presence of "guaranteed animal welfare" for steak would decrease consumers" marginal utility for "Guaranteed omega 3" and vice versa. The negative covariance also occurred for "guaranteed leanness" and "Guaranteed omega 3" (A12); "guaranteed animal welfare" and "Guaranteed omega 3" (A21); "guaranteed leanness" and "Guaranteed omega 3" (A21); "guaranteed leanness" and "guaranteed animal welfare" (A21); "guaranteed leanness" and "Guaranteed omega 3" (A22); and "guaranteed leanness" and "guaranteed animal welfare" (A22). The positive covariance among the other attributes indicates that the marginal utility of a meat attribute positively affects the other attributes.

For questionnaires B12 and B23, the covariance matrix demonstrates that most of the random parameters had positive relationships among them (Table 5). Attributes "Guaranteed omega 3" and "guaranteed Vitamin E" in B12 and B21 and "guaranteed 


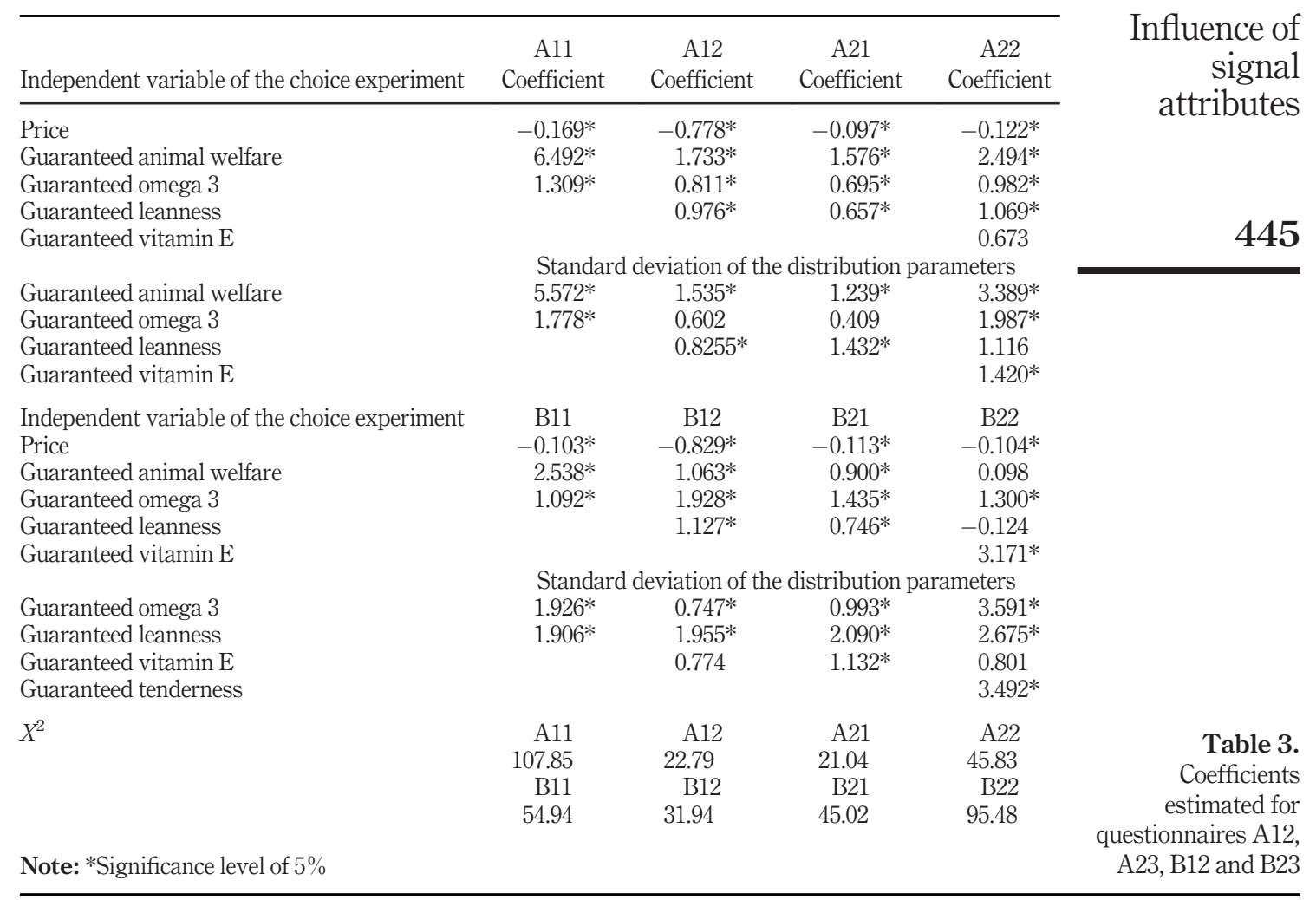

Vitamin E" and "guaranteed leanness" had negative covariances, which indicate a negative relationship between these attributes for the choices presented. Respondents showed heterogeneous preferences for all attributes of the B11 and B21 choices. Attribute "guaranteed Vitamin E" was not statistically significant in the B12 and B22 choices.

In addition to the analysis of coefficients, the WTP estimate for each attribute in each $\mathrm{CE}$ was carried out as follows.

4.2.2 Willingness-to-pay and the influence of signal attribute. With estimates of consumer WTP for each attribute, the impact of inserting additional attributes for each CE can be measured. Consumer WTP for a meat attribute is the ratio of the coefficient on the attribute and price: $W T P_{k}=\frac{\beta_{k}}{\alpha}$, where $\beta_{k}$ is the coefficient on the $\mathrm{k}^{\text {th }}$ attribute of an alternate and $\propto$ the price coefficient. A bootstrap procedure was used to generate 1,000 coefficient values for each attribute of meat, so that 1,000 WTP were simulated for each attribute of each steak and on each $\mathrm{CE}$.

Tables 6 and 7 present the average WTP simulated for each attribute of each choice for questionnaires A12 and A23 and B12 and B23, respectively. The total WTP is the amount (in Brazilian Real) that a consumer would be willing to pay for a steak that had all attributes present in every choice. All WTP estimates were different from zero at a 5\% significance level for questionnaires A12 and A23 (Table 7). The results showed that the WTP was 
RAUSP

55,4

446

\section{Table 4.}

Covariance matrix of random parameters for questionnaires A12 and A23

\begin{tabular}{|c|c|c|c|c|}
\hline A11 & $\begin{array}{c}\text { Guaranteed animal } \\
\text { welfare }\end{array}$ & $\begin{array}{l}\text { Guaranteed } \\
\text { omega } 3\end{array}$ & & \\
\hline $\begin{array}{l}\text { Guaranteed animal } \\
\text { welfare }\end{array}$ & 31.046 & & & \\
\hline Guaranteed omega 3 & 5.414 & 3.160 & & \\
\hline A12 & $\begin{array}{c}\text { Guaranteed animal } \\
\text { welfare }\end{array}$ & $\begin{array}{c}\text { Guaranteed } \\
\text { omega } 3\end{array}$ & $\begin{array}{c}\text { Guaranteed } \\
\text { leanness }\end{array}$ & \\
\hline $\begin{array}{l}\text { Guaranteed animal } \\
\text { welfare }\end{array}$ & 2.357 & & & \\
\hline Guaranteed omega 3 & -0.285 & 0.362 & & \\
\hline Guaranteed leanness & 0.474 & -0.094 & 0.682 & \\
\hline A21 & $\begin{array}{c}\text { Guaranteed animal } \\
\text { welfare }\end{array}$ & $\begin{array}{c}\text { Guaranteed } \\
\text { omega } 3\end{array}$ & $\begin{array}{c}\text { Guaranteed } \\
\text { leanness }\end{array}$ & \\
\hline $\begin{array}{l}\text { Guaranteed animal } \\
\text { welfare }\end{array}$ & 1.535 & & & \\
\hline Guaranteed omega 3 & -0.104 & 0.167 & & \\
\hline Guaranteed leanness & -0.519 & -0.430 & 2.051 & \\
\hline A22 & $\begin{array}{c}\text { Guaranteed animal } \\
\text { welfare }\end{array}$ & $\begin{array}{c}\text { Guaranteed } \\
\text { omega } 3\end{array}$ & $\begin{array}{c}\text { Guaranteed } \\
\text { leanness }\end{array}$ & $\begin{array}{c}\text { Guaranteed vitamin } \\
\text { E }\end{array}$ \\
\hline $\begin{array}{l}\text { Guaranteed animal } \\
\text { welfare }\end{array}$ & 11.487 & & & \\
\hline Guaranteed omega 3 & 2.600 & 3.948 & & \\
\hline Guaranteed leanness & -0.219 & -0.231 & 1.245 & \\
\hline Guaranteed vitamin $\mathrm{E}$ & 3.987 & 2.817 & -0.172 & 2.015 \\
\hline
\end{tabular}

\begin{tabular}{|c|c|c|c|c|}
\hline B11 & $\begin{array}{c}\text { Guaranteed } \\
\text { omega } 3\end{array}$ & $\begin{array}{c}\text { Guaranteed } \\
\text { leanness }\end{array}$ & & \\
\hline $\begin{array}{l}\text { Guaranteed omega } 3 \\
\text { Guaranteed leanness }\end{array}$ & $\begin{array}{l}3.710 \\
1.204\end{array}$ & 3.631409 & & \\
\hline $\begin{array}{l}\text { B12 } \\
\text { Guaranteed omega } 3 \\
\text { Guaranteed leanness } \\
\text { Guaranteed vitamin E }\end{array}$ & $\begin{array}{c}\text { Guaranteed } \\
\text { omega } 3 \\
0.559 \\
-0.357 \\
0.358\end{array}$ & $\begin{array}{c}\text { Guaranteed } \\
\text { leanness } \\
\\
3.823 \\
0.876\end{array}$ & $\begin{array}{c}\text { Guaranteed } \\
\text { vitamin E } \\
\\
0.600\end{array}$ & \\
\hline $\begin{array}{l}\text { B21 } \\
\text { Guaranteed omega } 3 \\
\text { Guaranteed leanness } \\
\text { Guaranteed vitamin E }\end{array}$ & $\begin{array}{c}\text { Guaranteed } \\
\text { omega } 3 \\
0.985 \\
-0.586 \\
0.758\end{array}$ & $\begin{array}{c}\text { Guaranteed } \\
\text { leanness } \\
\\
4.367 \\
1.181\end{array}$ & $\begin{array}{l}\text { Guaranteed } \\
\text { vitamin E }\end{array}$ & \\
\hline $\begin{array}{l}\text { B22 } \\
\text { Guaranteed omega } 3 \\
\text { Guaranteed leanness } \\
\text { Guaranteed vitamin E } \\
\text { Guaranteed tenderness }\end{array}$ & $\begin{array}{c}\text { Guaranteed } \\
\text { omega } 3 \\
12.894 \\
1.709 \\
0.860 \\
7.598\end{array}$ & $\begin{array}{l}\text { Guaranteed } \\
\text { leanness } \\
\\
7.153 \\
-0.195 \\
2.932\end{array}$ & $\begin{array}{l}\text { Guaranteed } \\
\text { vitamin E }\end{array}$ & $\begin{array}{l}\text { Guaranteed } \\
\text { leanness }\end{array}$ \\
\hline
\end{tabular}


higher for the attribute "guaranteed animal welfare," followed by "guaranteed leanness," "Guaranteed omega 3" and finally "guaranteed Vitamin E."

Tables 6 and 7 also show the ratio of consumer WTP for each attribute of a choice, calculated by the formula $W T P p=\frac{W T P^{k}}{W T P T \text { tal }}$. As can be seen, the higher this ratio, the greater the importance of the attribute. For example, for a steak in which only the attributes "guaranteed animal welfare" and "Guaranteed omega 3" are present (A11), the first accounted for $87.1 \%$ of the total WTP. "Guaranteed animal welfare" was the most important attribute in all choices, which confirms the $H 1 a$.

With WTP proportions, it is possible to make comparisons within and between them. At first, when adding an attribute (A12), the importance of WTP for "guaranteed animal welfare" decreases between A11 and A12 ("guaranteed leanness" as an additional attribute), as in A21 and A22 ("guaranteed Vitamin E" as a signal attribute). The WTP for "Guaranteed omega 3" gains importance between A11-A12 (within) and A12-A21 (between), but loses it between A12-A22 (within) and A21-A22 (between).

In Table 7, all estimates of choices B11, B12 and B21 are different from zero at a 5\% significance level. It is observed that, without the signal attribute "guaranteed animal welfare," "Guaranteed omega 3" gains greater importance to the detriment of "guaranteed leanness" in CE B11. However, the analyzes within (B11-B12) and between (B11-B21) and B11 show that, when attribute "guaranteed Vitamin E" is added, "guaranteed leanness" starts having greater importance for consumer WTP.

In experiment B22, while adding the attribute "guaranteed tenderness," the WTP, and hence, its proportions are negative for attributes "Guaranteed omega 3" and "guaranteed leanness," having no statistical significance. However, consumers were willing to pay R $\$ 34.24$ or more, at a significance level of $5 \%$, for beef of "guaranteed tenderness."

When comparing the results between questionnaires A12 and A23 (Table 6) with questionnaires B12 and B23 (Table 7), respectively, the signal attribute "guaranteed animal welfare" was the one with the highest proportion (importance) among the CEs. "Guaranteed tenderness" presented a share of $184.2 \%$ in the B22 CE, but the two attributes were not

\begin{tabular}{lrrrrrrrr}
\hline Attributes & A11 & A12 & A21 & A22 & A11 (\%) & A12(\%) & A21 (\%) & A22 (\%) \\
\hline Guaranteed animal welfare & $3,906^{*}$ & $26.61^{*}$ & $15.93^{*}$ & $17.52^{*}$ & 87.4 & 54.0 & 53.7 & 45.0 \\
Guaranteed omega 3 & $5.63^{*}$ & $10.98^{*}$ & $6.52^{*}$ & $7.57^{*}$ & 12.6 & 22.3 & 22.0 & 19.4 \\
Guaranteed leanness & & $11.70^{*}$ & $7.23^{*}$ & $9.67^{*}$ & & 23.7 & 24.4 & 24.8 \\
Guaranteed vitamin E & & & & $4.18^{*}$ & & & 10.7 \\
Total WTP & 44.69 & 49.29 & 29.68 & 38.95 & 100 & 100 & 100 & 100
\end{tabular}

Note: *Significance level of $5 \%$

Influence of signal attributes

$-2$ 
RAUSP

55,4

448

statistically significant, which makes this percentage not very concise due to two factors. First, when considering the findings of Lusk and Fox (2000), Goss et al. (2002), Feldkamp et al. (2003) and Hoffmann (2000) that tenderness is the most important attribute in a choice, the WTP for other attributes may have suffered some sort of "rejection." Second, the "tyranny of choice," defined by Sobal and Bisogni (2009) as "the excess or confusion of information" may be an explanation for this result, as they are different attributes and one of them (tenderness) has a preference that is statistically high.

Finally, comparisons within-subjects were made between CEs A11-A12, B11-B12, A21A22 and B21-B22, and comparisons between-subjects between experiments the A11-A21, B11-B21, A12-A22 and B12-B22. For both types of comparisons, the T-test was used, which determined the mean WTP difference between CEs. For example, the value 12.45 in Table 8 was calculated from the difference between the means 39.06 (A11) and 23.61 (A12), as shown in Table 6 , using a $T$-test with a $5 \%$ significance level.

In Table 8, the positive values mean there was a decrease in WTP between the experiments in question, while the negative ones increased. The results show that the WTP for attribute "guaranteed animal welfare" decreased by adding "Guaranteed omega 3" between CEs A11-A12, A11-A21, A12-A22, but showed a slight increase in experiment A21 with the introduction of "guaranteed Vitamin E" in experiment A22. In general, as attributes are added, the WTP for "guaranteed animal welfare" decreases and that of "Guaranteed omega 3" increases. Thus, by adding independent attributes, the signal attribute, which serves as a proxy for other quality attributes loses WTP, confirming $H 1 b$.

When comparing the CEs of questionnaires B12 and B23, the WTP for attribute "Guaranteed omega 3" also decreases with additional attributes. This finding is in line with Gao (2007), who found that, as additional information is passed onto consumers, the WTP for additional attributes decreases.

Finally, a $T$-test comparing the averages between the WTP of attributes "guaranteed animal welfare" of experiment A22 and "guaranteed tenderness" of B22 was carried out (Table 9). These experiments were chosen for having the same amount and attributes. Both the WTPs of "guaranteed animal welfare" and "guaranteed tenderness" used a significance level of $5 \%$.

Table 8.

Comparisons within and between-subjects

\begin{tabular}{|c|c|c|c|c|c|c|c|c|}
\hline Type of comparison & \multicolumn{2}{|c|}{ Within-subject } & \multicolumn{2}{|c|}{ Between subject } & \multicolumn{2}{|c|}{ Within-subject } & \multicolumn{2}{|c|}{ Between subject } \\
\hline Cho & $\mathrm{A} 11-\mathrm{A} 12$ & A21-A22 & $\mathrm{A} 11-\mathrm{A} 21$ & $\mathrm{~A} 12-\mathrm{A} 22$ & $\mathrm{~B} 11-\mathrm{B} 12$ & $\mathrm{~B} 21-\mathrm{B} 22$ & B11-B21 & B12-B22 \\
\hline $\begin{array}{l}\text { Guaranteed animal } \\
\text { welfare }\end{array}$ & & & & 9. & & & & \\
\hline Guaranteed omega 3 & -5.35 & -1.05 & -0.89 & 3.41 & 7.41 & 34.02 & 13.44 & 40.05 \\
\hline Guaranteed leanness & & -2.44 & & 6.09 & -12.78 & 3.21 & -2.27 & 13.72 \\
\hline Guaranteed vitamin $\mathrm{E}$ & & & & & & 5.16 & & 12.92 \\
\hline
\end{tabular}

\section{Table 9.}

Comparison between the WTPs of animal welfare and tenderness

\begin{tabular}{lrr}
\hline Type of comparison & WTP & Deviation \\
\hline "Guaranteed animal welfare” (A22) & 17.52 & 4.83 \\
"Guaranteed tenderness" (B22) & 34.24 & 8.53 \\
Difference - T-test (5\% significance level) & -16.72 & \\
\hline
\end{tabular}


As a result, the WTP of attribute "guaranteed softness" was statistically higher than that of "guaranteed animal welfare," with a difference of 16.72 , which confirms $H 2$.

\subsection{Results of laddering and choice experiments}

As values are crucial for evaluating products, and their attributes and consumer WTP corresponds to the value given to them, understanding how the WTP for attributes are related to the values is important to plan marketing campaigns, packaging and actions at sales points. The results of the CEs showed that consumers are willing to pay more for beef with "animal welfare guaranteed." In addition, this attribute can be linked to the following values: achievement, safety and universalism. Achievement is related to "feeling good, healthy and happy when consuming meat produced with animal welfare in mind." Safety is "to make sure you are eating a safe beef because the production considered the animal's care." In addition, Universalism is because you think about society and animals as a whole.

\section{Final considerations}

The purpose of this study was to identify the marginal impact of introducing a signal attribute of pasture-raised beef to consumer WTP for other independent attributes. To this end, two specific goals were set:

(1) To investigate the values of consumers regarding livestock production.

(2) To determine whether, with additional information, consumer WTP for a signal attribute changes.

According to the specific objectives, the study was divided into three steps.

The first objective was achieved in the first step, under which 52 interviews were conducted: 30 with consumers in Brazil and 22 in the USA. The results showed that consumers from both countries (in addition to the values that they have for beef production) consider aspects of the livestock. For Brazilians, security was the most important value, being the result of concerns over health issues and food safety. For US consumers, production is connected to consumer choice and the value of self-direction was considered a necessity, and must be carried out safely.

The second objective was achieved in Step 2 of this study, in which 267 beef consumers participated in CEs distributed in the form of physical questionnaires and surveys. The results show that WTP for the attribute "guaranteed animal welfare" was the most important in all four CEs of questionnaires A12 and A23, which confirmed H1a.

By adding independent attributes, the WTP for the signal attribute decreased, confirming H1b. This result is in line with the results of Gao (2007), who found that, as additional information is passed onto consumers, the WTP for additional attributes decreases. Finally, the comparison between the WTP of attribute "guaranteed animal welfare" of CE A22 and "guaranteed tenderness" of experiment B22 showed that consumer WTP was higher for tenderness than for animal welfare. Just as in Lusk and Fox (2000), Goss et al. (2002), Feldkamp et al. (2003) and Hoffmann (2000), and in the responses of the two experts, tenderness proved to be an important attribute for purchasing decisions.

Like the results of Umberger, Feuz, Calkins, and Sitz (2003), Conner and Oppenheim (2008) and Harper and Henson (2001), this study showed that consumers are willing to pay more for the attributes of pasture-raised meat, especially animal welfare. These findings offer alternate beef differentiation, in which it can be sold at higher added value by integrating these attributes.
Influence of signal attributes 
RAUSP

55,4
The present study filled a gap for studies regarding WTP and food consumers in Brazil. The review of the random parameter model and the construction method of the experiment may serve as a basis for other researchers interested in using this approach.

In addressing Brazilian consumer preference for beef produced on pasture, this innovative study has made a theoretical and practical contribution. First, because there have been few previous studies on the topic. Second, only isolated initiatives have been identified that distinguish meat from pasture and meat from confinement, such as Nelore Natural and Alianza del Pastizal.

The research is in line with Brazilian beef production as, according to ABIEC (2015), an estimated $97 \%$ of the national herd is pasture-raised. However, as Interviewee 1 observed, many slaughterhouses slaughter animals from different farms, thereby making control difficult. Interviewee 1 additionally commented that there is a lack of regulation and standardization regarding what is in fact confinement or pasture.

Based on its findings, the present study considers that meat produced on pasture is a differential, presenting attributes that consumers are willing to pay for. However, the experience of the two interviewees suggests that it is a product with potential for the premium retail market, one which has total control over production or which produces, and caters for a demanding, high purchasing-power clientele. Thus, it is concluded that, at least in the short term, pasture-raised beef is an ideal product for boutique butchers.

In relation to marketing strategy, as long as the terms are not standardized and there are no rules, terms that are already used by brands such as Korin, Granfine and Seara with chicken meat, for example, "raised free in nature," may be adopted.

It is important to note that the intention is not to replace confined meat with meat produced from pasture-raised animals, but for the latter to serve a market niche. According to the president of JBS, a leading Brazilian food industry, when referring to a new chicken brand marketed by Seara, "there is space for both types of consumption and, as with the Da Granja line, we want to serve consumers who appreciate light, healthy and practical products" (VAZ, 2015, p. 1).

One conclusion of the study was that the more attributes a product has, the less consumers are willing to pay for those attributes considered more important. For this reason, packaging must be quantitatively and qualitatively designed, especially when there is important information to be passed on.

Finally, this study recognizes certain limitations regarding the protocols adopted for its consumer surveys. Although more than half of the participant sample was randomly selected (downtown and in a park of Campinas), the other half was the result of convenience. In the USA, the sample partly comprising undergraduate students. In Step 3, for example, respondents answered by means of surveys and, although these were mainly distributed through a specialized meat blog, the sample was significantly unrepresentative. The questionnaires with college students also demonstrated a limitation: that is although students may have greater access to information, they often have lower incomes. The sample as a whole could also have been more comprehensive.

Jensen and Meckling (1994) discusses some theoretical model approaches to the study of human behavior: among them, the economic model, sociological model, psychological model and the political model. In the context of Brazilian consumer research, the psychological model represents the mainstream. This study, based on the economic model or the homoeconomicus point of view, exploring WTP, could complement and broaden the understanding of what are the specificities of the Brazilian consumer, and open a new front of investigation for market researchers. 
One suggestion for future studies would be to apply other methods, such as conjoint analysis and contingent valuation. Given the limited focus of this study, future research could also test WTP considering other socio-environmental attributes applied to animal protein or even other foods within the context of an emerging country. A study using an eyetracking method could effectively explore the importance consumers place on sustainable attributes and investigate how consumers' visual attention to sustainable attribute information on foods might influence their WTP for beef choice. Using experiments, some well-known and other "sustainable" brands could be tested to more clearly measure consumer purchase intentions with respect to these products. The same socio-environmental attributes researched in this study should be tested in other countries to understand behavioral differences between consumers in emerging and non-emerging countries with respect to sustainable attributes in beef. Finally, it is suggested that similar studies replicate the model with a larger, more concentrated sample.

\section{References}

ABIEC (2015). Qualidade da carne. Retrieved from www.abiec.com.br/3_qualidade.asp (accessed 15 January 2015).

Alpizar, F., Carlsson, F., \& Martinsson, P. (2003). Using choice experiments for Non-Market valuation. Economic Issues Journal Articles, 8(1), 83-110.

Anderson, J. C., Jain, D. C., \& Chintagunta, P. K. (1992). Customer value assessment in business markets: a state-of-Practice study. Journal of Business-to-Business Marketing, 1(1), 3-29. https:// doi.org/10.1300/J033v01n01_02.

Becker, T. (2000). Consumer perception of fresh meat quality: a framework for analysis. British Food Journal, 102(3), 158-176. https://doi.org/10.1108/00070700010371707.

Cheah, J.-H., Ting, H., Thaichon, P., Fam, K.-S., \& Bazylewich, M. (2020). Can positioning strategies help influence willingness to pay for office space? evidence on the moderating effect of office space grade and industry sector for occupiers of leased office space. Journal of Strategic Marketing, $1466-4488$.

Chini, J. (2015). Influência do atributo de sinal na disposição a pagar pela carne bovina produzida no pasto.

Clark, B., Stewart, G. B., Panzone, L. A., Kyriazakis, I., \& Frewer, L. J. (2016). A systematic review of public attitudes, perceptions and behaviours towards production diseases associated with farm animal welfare. Journal of Agricultural and Environmental Ethics, 29(3), 455-478. https://doi.org/ 10.1007/s10806-016-9615-x.

Cliceri, D., Spinelli, S., Dinnella, C., Ares, G., \& Monteleone, E. (2019). Consumer categorization of plantbased dishes: Implications for promoting vegetable consumption. Food Quality and Preference, 76, 133-145. https://doi.org/10.1016/j.foodqual.2019.04.002.

Conner, D. S., \& Oppenheim, D. (2008). Demand for pasture-raised livestock products: Results from Michigan retail surveys. Journal of Agribusiness, 26(1), 1-20.

Cusielo, K. V. C., da Silva, A. C. D. M. L., Tavares-Filho, E. R., \& Bolini, H. M. A. (2019). Sensory influence of sweetener addition on traditional and decaffeinated espresso. Journal of Food Science, 84(9) doi: https://doi.org/10.1111/1750-3841.14773.

Davvetas, V., Sichtmann, C., \& Diamantopoulos, A. (2015). The impact of perceived Brand globalness on consumers' willingness to pay. International Journal of Research in Marketing, 32(4), 431-434. https://doi.org/10.1016/j.jiresmar.2015.05.004.

Di Vita, G., Blanc, S., Brun, F., Bracco, S., \& D’Amico, M. (2019a). Quality attributes and harmful components of cured meats: Exploring the attitudes of italian consumers towards healthier cooked ham. Meat Science, 155, 8-15. https://doi.org/10.1016/j.meatsci.2019.04.013.

Influence of signal attributes 
RAUSP

55,4

Di Vita, G., Pappalardo, G., Chinnici, G., La Via, G., \& D’Amico, M. (2019b). Not everything has been still explored: Further thoughts on additional price for the organic wine. Journal of Cleaner Production, 231, 520-528. https://doi.org/10.1016/j.jclepro.2019.05.268.

Dickson, D. L., \& Bailey, D. V. (2002). Meat traceability: Are U.S. consumers willing to pay for it? Journal of Agriculture and Resource Economics, 27(2), 348-364.

Evans, J. R. (2007). Determining consumer perceptions of and willingness to pay for appalachian GrassFed beef: an experimental economics approach. Thesis Ph.D, Morgantown: Davis college of agriculture. Forestry, and consumer sciences at WV university.

Evans, J. R., D'Souza, G. E., Collins, A., Brown, C., \& Sperow, M. (2011). Determining consumer perceptions of and willingness to pay for appalachian grass-fed beef: an experimental economics approach. Agricultural and Resource Economics Review, 40(2), 233-250. https://doi.org/10.1017/ S1068280500008030.

Feldkamp, T., Schroeder, T., \& Lusk, J. (2003). Consumer valuation of steaks with different quality attributes. Report of Progress, 908

Furst, T., Connors, M., Bisogni, C. A., Sobal, J., \& Falk, L. W. (1996). Food choice: a conceptual model of the process. Appetite, 26(3), 247-266. https://doi.org/10.1006/appe.1996.0019.

Gao, Z. (2007). Effects of additional quality attributes on consumer willingness-to-pay for food labels, Doctoral dissertation, Kansas State University.

Gao, Z., \& Schroeder, T. C. (2009). Effects of label information on consumer willingness-to-pay for food attributes. American Journal of Agricultural Economics, 91(3), 795-809. https://doi.org/10.1111/ j.1467-8276.2009.01259.x.

Gao, Z., House, L. O., \& Yu, X. (2010). Using choice experiments to estimate consumer valuation: the role of experimental design and attribute information loads. Agricultural Economics, 41(6), 555565. https://doi.org/10.1111/j.1574-0862.2010.00470.x.

Gębski, J., Jezewska-Zychowicz, M., Szlachciuk, J., \& Kosicka-Gębska, M. (2019). Impact of nutritional claims on consumer preferences for bread with varied fiber and salt content. Food Quality and Preference, 76, 91-99. https://doi.org/10.1016/j.foodqual.2019.03.012.

Goss, J., Holcomb, R. B., \& Ward, C. E. (2002). Factors influencing consumer decisions related to natural beef in the Southern plains. Journal of Food Distribution Research, 33(1), 73-84.

Grandin, T. (2019). Crossing the divide between academic research and practical application of ethology and animal behavior information on commercial livestock and poultry farms. Applied Animal Behaviour Science, 218 doi: https://doi.org/10.1016/j.applanim.2019.06.009.

Harper, G., \& Henson, S. (2001). Consumer concerns about animal welfare and the impact on food choice. EU FAIR CT98-3678, The University of Reading, Centre for Food Economics Research.

Harper, G. C., \& Makatouni, A. (2002). Consumer perception of organic food production and farm animal welfare. British Food Journal, 104(3/4/5), 287-299. https://doi.org/10.1108/ 00070700210425723.

Heise, H., \& Theuvsen, L. (2018). German dairy farmers' attitudes toward farm animal welfare and their willingness to participate in animal welfare programs: a cluster analysis. International Food and Agribusiness Management Review, 21(8), 1121-1136. https://doi.org/10.22434/IFAMR2017.0066.

Hoag, T. M., \& Lemme, C. F. (2018). Animal-derived food industry: risks and opportunities due to farm animal welfare. Revista de Administração de Empresas, 58(3), 244-253. https://doi.org/10.1590/ s0034-759020180305.

Hoffmann, R. (2000). Country of origin-a consumer perception perspective of fresh meat. British Food Journal, 102(3), 211-229. https://doi.org/10.1108/00070700010332304.

Holloway, R. J., \& White, T. (1964). Advancing the experimental method in marketing. Journal of Marketing Research, 1(1), 25-29. https://doi.org/10.2307/3150315. 
Homburg, C., Lauer, K., \& Vomberg, A. (2019). The multichannel pricing dilemma: Do consumers accept higher offline than online prices? International Journal of Research in Marketing, 36(4), 597-612. https://doi.org/10.1016/j.ijresmar.2019.01.006.

Hoppe, A., De Barcellos, M. D., Vieira, L. M., \& de Matos, C. A. (2012). Comportamento do consumidor de produtos orgânicos: uma aplicação da teoria do comportamento planejado. BASE - Revista de Administração e Contabilidade da Unisinos, 9(2), 174-188. https://doi.org/10.4013/ base.2012.92.06.

Huber, J., \& McCann, J. (1982). The impact of inferential beliefs on product evaluations. Journal of signal attributes Marketing Research, 19(3), 324-333. https://doi.org/10.2307/3151566.

Huffman, K. L., Miller, M. F., Hoover, L. C., Wu, C. K., Brittin, H. C., \& Ramsey, C. B. (1996). Effect of beef tenderness on consumer satisfaction with steaks consumed in the home and restaurant. Journal of Animal Science, 74(1), 91-97. https://doi.org/10.2527/1996.74191x.

Jensen, M. C., \& Meckling, W. H. (1994). The nature of man. Journal of Applied Corporate Finance, 7(2), 4-19. https://doi.org/10.1111/j.1745-6622.1994.tb00401.x.

Jorquera-Chavez, M., Fuentes, S., Dunshea, F. R., Jongman, E. C., \& Warner, R. D. (2019). Computer vision and remote sensing to assess physiological responses of cattle to pre-slaughter stress, and its impact on beef quality: a review. Meat Science, 156(10), 11-22. https://doi.org/10.1016/j. meatsci.2019.05.007.

Kalish, S., \& Nelson, P. (1991). A comparison of ranking, rating and reservation price measurement in conjoint analysis. Marketing Letters, 2(4), 327-335. https://doi.org/10.1007/ BF00664219.

Kiatkawsin, K., \& Han, H. (2019). What drives customers' willingness to pay price premiums for luxury gastronomic experiences at michelin-starred restaurants?. International Journal of Hospitality Management, 82, 209-219. https://doi.org/10.1016/j.ijhm.2019.04.024.

Kirchner, M. K., Koštõál, L., Bilč́́k, B., \& Winckler, C. (2017). Mapping farm animal welfare research in an enlarged Europe: international collaboration, bibliometric output, research resources and relation to economic indices. Scientometrics, 113(2), 909-922. https://doi.org/10.1007/s11192-0172505-9.

Koknaroglu, H., \& Akunal, T. (2013). Animal welfare: an animal science approach. Meat Science, 95(4), 821-827. https://doi.org/10.1016/j.meatsci.2013.04.030.

Kolady, D. E., Kattelmann, K., \& Scaria, J. (2019). Effects of health-related claims on millennials' willingness to pay for probiotics in the US: Implications for regulation. Journal of Functional Foods, 60, 103434. https://doi.org/10.1016/j.jff.2019.103434.

Koschate-Fischer, N., Diamantopoulos, A., \& Oldenkotte, K. (2012). Are consumers really willing to pay more for a favorable country image? a study of country-of-Origin effects on willingness to pay. Journal of International Marketing, 20(1), 19-41. https://doi.org/ 10.1509/jim.10.0140.

Krinsky, I., \& Robb, A. L. (1986). On approximating the statistical properties of elasticities. The Review of Economics and Statistics, 68(4), 715-719. https://doi.org/10.2307/1924536.

Lancaster, K. J. (1966). A new approach to consumer theory. The. Journal of Political Economy, 74(2), 132-157. https://doi.org/10.1086/259131.

Le Gall-Ely, M. (2009). Definition, measurement and determinants of the consumer's willingness to pay: a critical synthesis and avenues for further research. Recherche et Applications en Marketing (English Edition), 24(2), 91-112. https://doi.org/10.1177/205157070902400205.

Li, S. W., Chen, Z. H. U., Chen, Q. H., \& Liu, Y. M. (2019). Consumer confidence and consumers' preferences for infant formulas in China. Journal of Integrative Agriculture, 18(8), 1793-1803. https://doi.org/10.1016/S2095-3119(19)62589-X.

López-Galán, B., \& de-Magistris, T. (2019). Testing emotional eating style in relation to willingness to pay for nutritional claims. Nutrients, 11(8), 1773. https://doi.org/10.3390/nu11081773. 
RAUSP

55,4

Loureiro, M. L., \& Umberger, W. J. (2003). Estimating consumer willingness to pay for country-of-origin labeling. Journal of Agricultural and Resource Economics, 287-301.

Low, G., \& Lamb, C. Jr, (2000). The measurement and dimensionality of Brand associations. “Journal of Product \& Brand Management, 9(6), 350-370. https://doi.org/10.1108/10610420010356966.

Ludwiczak, A., Bykowska-Maciejewska, M., Składanowska-Baryza, J., \& Stanisz, M. (2019). Influence of the method of storage on the quality of venison from wild fallow deer (dama dama). Meat Science, 156, 98-104. https://doi.org/10.1016/j.meatsci.2019.05.021.

Lusk, J. L., \& Fox, J. A. (2000). Consumer valuation of beef ribeye steak attributes. Proceedings of American Agricultural Economics Association annual meeting. Tampa, FL, August.

Lusk, J. L., \& Schroeder, T. C. (2004). Are choice experiments incentive compatible? A test with quality differentiated beef steaks. American Journal of Agricultural Economics, 86(2), 467-482.

Lusk, J. L., Roosen, J., \& Fox, J. A. (2003). Demand for beef from cattle administered growth hormones or fed genetically modified corn: a comparison of consumers in France, Germany, the United Kingdom, and the United States. American Journal of Agricultural Economics, 85(1), 16-29. https://doi.org/10.1111/1467-8276.00100.

McCausland, C. (2014). The five freedoms of animal welfare are rights. Journal of Agricultural and EnvironmentalEthics, 27(4), 649-662. https://doi.org/10.1007/s10806-013-9483-6.

Mahieu, P. A. Andersson, H. Beaumais, O. Crastes, R., \& Wolff, F. C. (2014). Is choice experiment becoming more popular than contingent valuation? a systematic review in agriculture, environment and health. FAERE Working Paper, 12.

Makatouni, A. (2002). What motivates consumers to buy organic food in the UK? results from a qualitative study. British Food Journal, 104(3/4/5), 345-352. https://doi.org/10.1108/ 00070700210425769.

Matsumoto, S. (2004). Consumers' responses to front vs. Back package GM labels in Japan. Journal of Agricultural \& Food Industrial Organization, 2(1), 25. https://doi.org/10.2202/1542-0485.1050.

Nahuelhual, L., Loureiro, M. L., \& Loomis, J. (2004). Using random parameters to account for heterogeneous preferences in contingent valuation of public open space. Journal of Agricultural and Resource Economics, 537-552.

Nguyen, H., \& Wismer, W. V. (2019). A comparison of sensory attribute profiles and liking between regular and sodium-reduced food products. Food Research International, 123 doi: https://doi.org/ 10.1016/j.foodres.2019.05.037.

Nijland, H. J., Aarts, N. M., \& Renes, R. J. (2013). Frames and ambivalence in context: an analysis of hands-on experts' perception of the welfare of animals in traveling circuses in The Netherlands. Journal of Agricultural and Environmental Ethics, 26(3), 523-535. https://doi.org/10.1007/s10806010-9252-8.

O’Malley, C. I., Turner, S. P., D'Eath, R. B., Steibel, J. P., Bates, R. O., Ernst, C. W., \& Siegford, J. M. (2019). Animal personality in the management and welfare of pigs. Applied Animal Behaviour Science, 218, 218 doi: https://doi.org/10.1016/j.applanim.2019.06.002.

Ogunleke, A. O., \& Baiyegunhi, L. J. S. (2019). Households' acceptability of local (ofada) rice based on quality attributes in South-West. British Food Journal, 121(9) doi: https://doi.org/10.1108/BFJ-01-2019-0045.

Palczak, J., Blumenthal, D., \& Delarue, J. (2019). From consumption behaviour to sensory measurement: Sensory characterization of the perceived flavour complexity of a chocolate dessert experience. Food Quality and Preference, 78, 103734 doi: https://doi.org/10.1016/j. foodqual.2019.103734.

Pato-Oliveira, C., \& Tamayo, Á. (2002). Os valores como preditores de atitudes e comportamentos: contribuições Para um debate. Linhas Críticas, 8(14), 103-117. https://doi.org/10.26512/lc. v8i14.3003.

Pinto, L. A., Murakami, L. C., Pimenta, M. L., \& Nunes, N. S. (2012). Valores em serviços de policiamento comunitário: o programa ronda do quarteirão sob a ótica da teoria da cadeia 
de meios e fins. Revista de Administração Pública, 46(1), 333-357. https://doi.org/10.1590/ S0034-76122012000100016.

Pirog, R. (2004). Consumer perceptions of pasture-raised beef and dairy products: an internet study, Ames: IA State University, Leopold Center for Sustainable Agriculture.

Powell, P. A., Jones, C. R., \& Consedine, N. S. (2019). It's not queasy being green: the role of disgust in willingness-to-pay for more sustainable product alternatives. Food Quality and Preference, 78, 103737 doi: https://doi.org/10.1016/j.foodqual.2019.103737.

Reynolds, T. J., \& Gutman, J. (1988). Laddering theory, method, analysis, and interpretation. Journal of Advertising Research, 28(1), 11-31.

Rihn, A., Wei, X., \& Khachatryan, H. (2019). Text vs. logo: Does eco-label format influence consumers' visual attention and willingness-to-pay for fruit plants? an experimental auction approach. Journal of Behavioral and Experimental Economics, 82, 101452 doi: https://doi.org/10.1016/j. socec.2019.101452.

Schmidt, J., \& Bijmolt, T. H. A. (2019). Accurately measuring willingness to pay for consumer goods: a Meta-analysis of the hypothetical bias. Journal of the Academy of Marketing Science, 48(3), 1-20. https://doi.org/10.1007/s11747-019-00666-6.

Scholz, M., Dorner, V., Franz, M., \& Hinz, O. (2015). Measuring consumers' willingness to pay with utility-based recommendation systems. Decision Support Systems, 72, 60-71. https://doi.org/ 10.1016/j.dss.2015.02.006.

Schwartz, S. H. (1992). Universals in the content and structure of values: Theoretical advances and empirical tests in 20 countries. Advances in Experimental Social Psychology, 25(1), $1-65$.

Simonson, I., \& Drolet, A. (2004). Anchoring effects on consumers' willingness-to-pay and willingnessto-accept. Journal of Consumer Research, 31(3), 681-690. [Dawn Iacobucci served as editor and Barbara Kahn served as associate editor for this article]. https://doi.org/10.1086/425103.

Sobal, J., \& Bisogni, C. A. (2009). Constructing food choice decisions. Annals of Behavioral Medicine, 38(S1), 37-46. https://doi.org/10.1007/s12160-009-9124-5.

Steenkamp, J. B. E. M. (1990). Conceptual model of the quality perception process. Journal of Business Research, 21(4), 309-333. https://doi.org/10.1016/0148-2963(90)90019-A.

Stewart, J. M., O'Shea, E., Donaldson, C., \& Shackley, P. (2002). Do ordering effects matter in willingness-to-pay studies of health care? Journal of Health Economics, 21(4), 585-599. https:// doi.org/10.1016/S0167-6296(02)00003-6.

Tait, P., Saunders, C., Dalziel, P., Rutherford, P., Driver, T., \& Guenther, M. (2019). Estimating wine consumer preferences for sustainability attributes: a discrete choice experiment of californian sauvignon blanc purchasers. Journal of Cleaner Production, 233(10), 412-420. https://doi.org/ 10.1016/j.jclepro.2019.06.076.

Testa, R., Asciuto, A., Schifani, G., Schimmenti, E., \& Migliore, G. (2019). Quality determinants and effect of therapeutic properties in honey consumption. Agriculture, 9(8), 174 doi: https://doi.org/ 10.3390/agriculture9080174.

Tonsor, G. T., Schroeder, T. C., Fox, J. A., \& Biere, A. (2005). European preferences for beef steak attributes. Journal of Agricultural and Resource Economics, 30(2), 367-380.

Train, K. E. (1998). Recreation demand models with taste differences over people. Land Economics, 74(2), 230-239. https://doi.org/10.2307/3147053.

Umberger, W. J. (2004). Will consumers pay a premium for country-of-origin labeled meat?. Choices Magazine, 15-19.

Umberger, W. J., Feuz, D. M., Calkins, C. R., \& Sitz, B. M. (2003). Country-of-Origin labeling of beef products: U.S. Consumers' perceptions. Journal of Food Distribution Research, 34(3), 103-116.
Influence of signal attributes 
RAUSP

55,4

Vaz, T. (2015). Seara começa a vender frango sem antibiótico por 40\% mais. Portal Exame.Retrieved from http://exame.abril.com.br/negocios/noticias/seara-comeca-a-vender-frango-sem-antibioticopor-40-mais\#1 (accessed 18 November).

Vergura, D. T., Zerbini, C., \& Luceri, B. (2019). Palm oil free” vs "sustainable palm oil”: the impact of claims on consumer perception. British Food Journal, 121(9), 2027-2035. https://doi.org/10.1108/ BFJ-01-2019-0020.

Ward, C. E., Lusk, J. L., \& Dutton, J. M. (2008). Implicit value of retail beef product attributes. Journal of Agricultural and Resource Economics, 364-381.

Wertenbroch, K., \& Skiera, B. (2002). Measuring consumers' willingness to pay at the point of purchase. Journal of Marketing Research, 39(2), 228-241. https://doi.org/10.1509/jmkr.39.2.228.19086.

Zhao, R., Qiao, J., \& Chen, Y. (2010). Influencing factors of consumer willingness-to-buy traceable foods: An analysis of survey data from two Chinese cities. Agriculture and Agricultural Science Procedia, 1, 334-343.

\section{Corresponding author}

Eduardo Eugênio Spers can be contacted at: edespers@usp.br

Associate Editor: Filipe Quevedo-Silva

For instructions on how to order reprints of this article, please visit our website: www.emeraldgrouppublishing.com/licensing/reprints.htm

Or contact us for further details: permissions@emeraldinsight.com 